\title{
JOHN THE GRAMMARIAN AND LEO THE MATHEMATICIAN AS A TARGET OF ORTHODOX CRITICS: PARALLELS AND HISTORICAL CONTEXT ${ }^{1}$
}

\author{
Tatyana A. Senina (nun Kassia)
}

Saint Petersburg State University of Aerospace Instrumentation, Saint Petersburg, Russian Federation

\begin{abstract}
John the Grammarian and Leo the Mathematician and Philosopher, Byzantine intellectuals of the 9th century who played a major role in the revival of interest in the learning of classical culture in Byzantium, were attacked for their passion for the ancient culture and philosophy, particularly Platonism. Strictly Orthodox opponents accused them of impiety, sorcery and even the worship of pagan gods. Despite the absurdity of such accusations, they show that the orthodox fundamentalists denounced a manifest interest in "human wisdom", because they considered it as a danger for the "wisdom inspired by God". Patriarch Methodius of Constantinople accused John the Grammarian both of iconoclastic heresy and of passion for Hellenic writings. Constantine the Sicilian, a disciple of Leo the Philosopher, left his teacher and passed to the circle of admirers of the Patriarch Photios of Constantinople. After Leo's death Constantin blamed him for his apostasy and excessive devotion to the culture of ancient Greece. 40 years later, Leo Choirosphaktes, a disciple of Leo the Philosopher, was attacked by Arethas, Archbishop of Caesarea, with similar accusations. These cases indicate the presence of various trends among the Byzantine intellectuals of 9th century: one traditionally orthodox, personified by Patriarch Photius, and another more Hellenistic, headed by Leo the Philosopher.

Key words: John the Grammarian, Leo the Mathematician, Byzantine History, Byzantine Philosophy, Byzantine education, Iconoclasm, Hellinism.
\end{abstract}

\section{ИОАНН ГРАММАТИК И ЛЕВ МАТЕМАТИК ПОД ПРИЦЕЛОМ ОРТОДОКСАЛЬНОЙ КРИТИКИ: ПАРАЛЛЕЛИ И ИСТОРИЧЕСКИЙ КОНТЕКСТ ${ }^{1}$}

\section{Татьяна Анатольевна Сенина (монахиня Кассия)}

Аннотация. Иоанн Грамматик и Лев Математик и Философ, византийские интеллектуалы IX в., сыгравшие большую роль в возрождении интереса к эллинской учености в Византии, подверглись нападкам за свое увлечение античной культурой и философией, в частности, платонизмом. Строго православные оппоненты обвиняли их в нечестии, колдовстве и даже поклонении языческим богам. Несмотря на нелепость подобных 
обвинений, они показывают, что христианские фундаменталисты осуждали ярко выраженный интерес к «человеческой мудрости», опасаясь, что этим будет нанесен ущерб мудрости «богооткровенной». Случай Константина Сицилийца, который перешел от своего учителя Льва Философа в круг почитателей патриарха Константинопольского Фотия, а после смерти Льва обрушился на него с яростной критикой за приверженность античной культуре, свидетельствует о наличии разных течений среди византийских интеллектуалов IX в. - традиционно православного, олицетворяемого Фотием, и более эллинистического, которое возглавлял Лев Философ.

Ключевые слова: Иоанн Грамматик, Лев Математик и Философ, византийская философия, византийская образованность, иконоборчество, эллинизм.

Последний иконоборческий Константинопольский патриарх Иоанн Грамматик (770-е 863/867, патриарх 837-843) [6, с. 29-39, 125$128 ; 17 ; 18$, p. 123-135; 23, № 3199, 3304 ] и его племянник, известный ученый Лев Математик и Философ (790/800 - после 869) [4, с. 215 $258 ; 7 ; 14 ; 22 ; 23$, № 4440] являются наиболее заметными византийскими эллинистами IX века. Говоря о византийских эллинистах, я имею в виду тех интеллектуалов, которые не только имели хорошее светское образование и знали античную культуру, но и были увлечены ею гораздо больше, чем обычно для людей их круга, балансируя на той грани, за которой, с точки зрения обычного византийца, начиналось «нечестие». По мнению некоторых их современников, Иоанн и Лев перешли эту грань, не просто впав в ересь, но и вовсе отступив от христианской веры, о чем свидетельствуют яростные нападки на Иоанна со стороны патриарха Константинопольского Мефодия, а на Льва - со стороны его ученика Константина Сицилийца. Исследование причин и исторического контекста этой ортодоксальной критики в адрес двух ярких представителей византийской интеллектуальной элиты IX столетия интересно для выяснения идеологического и культурного климата той эпохи.

Эпоха, в которую жили Иоанн и Лев, была временем интеллектуального брожения и особенного роста интереса к античной литератуpe. C IX в. минускульное письмо начинает массово использоваться при создании рукописей вместо унциального, что позволяет умещать на листах гораздо бульшие объемы текста $[4$, с. $157-175]$; в результате возрастает объем вновь создаваемых и переписываемых древних произведений. С одной стороны, иконоборческая полемика всколыхнула умы и способствовала появлению новых богословских, агиографических и исторических сочине- ний. С другой стороны, в эпоху второго иконоборчества возрос интерес к светской культуре и наукам, и этот рост продолжался после Торжества православия. В IX в. было переписано заново - и таким образом спасено для потомков - очень много античных рукописей светского содержания: поэты, историки, астрономы и астрологи, медики, математики, географы, философы, собрания древних писем; при передаче Аристотеля больше внимания уделялось его научным работам, чем философским; зато был переписан большой объем платонических текстов - не только сам Платон, но и его комментаторы, такие как Прокл, Дамаский и другие [31, p. 85-88].

Ученые кружки вокруг известных интеллектуалов и учителей существовали на протяжении всей истории Византии. Особенно хорошо это явление прослеживается на примере поздней Византии [3, с. $138-151 ; 5$, с. $17-$ 24]; для IX в. из источников известен кружок патриарха Константинопольского Фотия [4, c. 289-293]. Иоанн, правда, занимался частным преподаванием, видимо, лишь до того как начал церковную карьеру, о чем свидетельствует его прозвище Грамматик, а впоследствии вращался в придворных кругах - был советником иконоборческих императоров и учителем последнего из них, Феофила; поэтому настоящего кружка учеников Грамматик мог и не иметь, ограничившись кругом ученых друзей и отдельных элитных учеников вроде императора. Зато Лев занимался преподаванием всю свою жизнь и, как высокообразованный эрудит, сначала частный преподаватель, затем глава покровительствуемой императором школы, а позднее и столичного Университета, должен был пользоваться огромным уважением и известностью; несомненно, он имел свой кружок учеников и друзей. 


\section{ВИЗАНТИЙСКОЕ ПРАВОСЛАВИЕ}

В таких ученых кружках изучали греческую философию и литературу, занимались стихосложением, писали эпиграммы на произведения античных авторов, читали и обсуждали различные сочинения, как древние, так и собственные, новонаписанные. Как мы можем понять из сочинений Льва, он отличался большой склонностью к эллинизму и относился к античному наследию с любовью, а не просто как к инструменту образования; он даже носил прозвище Эллин, зафиксированное в надписании к одной из его эпиграмм [9, Bd. IV, Buch XV, Ep. 12]. Сочинения Иоанна до нас, к сожалению, не дошли, поскольку все иконоборческие произведения были уничтожены после 843 г.; сохранилось лишь несколько богословских отрывков в составе двух анонимных антииконоборческих трактатов [11; 12]. Однако его хорошее светское образование подтверждается как тем, что он был учителем императора Феофила, так и тем, что даже крайне враждебные ему иконопочитатели признавали его ученость. Автор одного из житий св. Феодора Студита пишет об Иоанне:

«Заправилой их <иконоборцев> кружка ( $\tau \tilde{\eta} \varsigma$

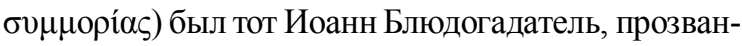
ный так своими собственными земляками - как мне думается, за приверженность к гаданиям и другим постыдным делам. Он, имея известный лживостью язык, был силен и превосходен в софизмах, сведущ во внешней науке и весьма проницателен в пустых вещах, - поэтому он и удостоился всяческой чести от тирана ${ }^{2}$, который пользовался им как языком и имел его помощником в делах» [28, § 61, col. 172AB].

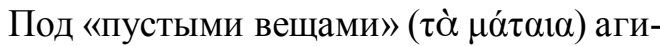
ограф-монах вполне мог иметь в виду мирские знания.

В другом Житии св. Феодора Иоанн описан так:

«Львонравный и тупоумный тот <император>.., найдя сосуды гнева, готовые к погибели (Рим. 9:22) - некоторых сверстников, разнузданных, праздных и привыкших ко злу, поистине лживых юнцов, заботившихся о телесной красоте и согласных с его желаниями, - устремляется вместе с ними к погибели и через них до всех доносит беззаконную и богоненавистную проповедь. Среди них был некто другой Ианний, а не Иоанном достойный называться, поскольку он первый направляется в этот лабиринт ${ }^{3},-$ человек, происшедший из земли Ac- сирийской ${ }^{4}$, новоявленный пустослов, рассказывающий им басни, а не истину, справедливо прозванный Блюдогадателем: как более других сведущий в грамматике, ужасное орудие глупейшей из всех лжи, человек порочнейший и способный приводить в смятение великие дела» [29, § 32, col. 277CD].

Патриарх Мефодий дает некоторые сведения об интеллектуальных вкусах Иоанна Грамматика в каноне на Торжество православия, написанном в 843 г. [27, б. 233-240] (в современных изданиях канон приписан Феодору Студиту, но на самом деле это творение Мефодия [4, с. 207-208]; в славянской Триоди канон отсутствует). Говоря об иконоборчестве Иоанна, Мефодий обвиняет его в том, что он «извратил отцов догматы и апостольские учения, по-иному (их) написуя, по своему беззаконному богопочитанию» $[27, \sigma .237$, песнь 6 , тропарь 5], излагал «несвященные догматы и противозаконные учения» [27, б. 234, п. 3, тр. 4]. Но интереснее всего утверждение, что Иоанн «явился равным эллинам, чванясь их писаниями, которые гласы праведных раз навсегда справедливо сокрушили» [27, б. 237, п. 7, тр. 5], и потому ему подобает называться не Иоанном (имя на еврейском означает «Божия благодать»), а «скорее Пифагором, Кроном или Аполлоном» [27, б. 238, п. 7, тр. 7], - здесь можно видеть не просто поношение, но и указание на светское образование и вкусы Грамматика: знание математики и античной мифологии (видимо, именно это символизирует Крон, отец главных олимпийских богов, в том числе Зевса, Геры, Аида и Посейдона), любовь к Музам, чьим предводителем считался Аполлон. Иоанн не раскаялся в иконоборчестве и окончил дни в своем имении на берегу Босфора, войдя в историю как злейший еретик.

Лев, в отличие от своего дяди-патриарха, хотя ненадолго примкнул к иконоборцам в царствование Феофила (829-842), после Торжества православия вернулся к иконопочитанию, как и большинство населения Империи. Несмотря на свое прошлое в качестве иконоборческого епископа Фессалоники, Лев после низложения с кафедры продолжал преподавать в светской школе и даже стал при императора Михаиле III (856-867) главой константинопольского Университета. Его приверженность к античной культуре, явная как из его 
эпиграмм, так и из поэмы «Иов, или О беспечалии и терпении» [7, с. 24-37], вызвала смущение у его ученика Константина Сицилийца, в какой-то момент перешедшего из кружка Льва в круг почитателей патриарха Фотия, который, несмотря на свою огромную ученость и любознательность, как отметил П. Лемерль, все же был прежде всего «человеком Церкви» и по своим интересам являлся гораздо менее гуманистом, чем Лев [4, c. 298,300 ; cp. 15, p. 105-106]. В своей элегии, где Константин отрекается от Муз, особенно же от музы лирической поэзии, и признается в любви к риторике, он говорит, что «обрел учителя - архиерея Фотия», который его «напитал молоком божественных струй» [30, p. 201].

Против Льва направлены стихи, написанные Константином сразу после смерти Философа. «Стихи героические и элегические» в трех частях называют античных ученых и философов, чью «внешнюю премудрость» преподавал Лев, «болтунами» [25, col. LXIA]. По словам Константина, Лев оставил христианство, «устремился в пучину эллинской пагубы», отрекся от Св. Троицы и поклонился «бесконечной толпе богов», за что Христос покарал его болезнью и смертью [25, col. LXIAB]. Сицилиец обращается ко Льву с пламенной речью:

«Злая глава, сгинь во мрачном жилище Аида! Прочь, злополучный, с такой мудростию и нечестьем К Пирифлегетону ${ }^{5}$, в Тартар широкий, несущий погибель,

Где можешь ты увидать и Сократа с Хрисиппом ${ }^{6}$, Прокла, Платона, еще Аристотеля и Эпикура, Также Евклида, друзей твоих - учеников Птолемея, С ними же и мудреца, что поистине царственней прочих ${ }^{7}$

Музу Гомеровскую, Гесиода, а также Арата ${ }^{8}$. Не негодуй на вечный огнь, взлелеянный тебе Совместно с замечательным сим хороводом Тех, кого ты обожествлял и чествовал чрезмерно, С благоволеньем относясь к обманам их сокрытым!» [25, col. LXIC, LXIVA].

Константин якобы «с трудом и поздно понял сокрытый порок» своего учителя и решил рассказать об этом во всеуслышание [25, col. LXIVA]. Эти стихи, будучи обнародованы, вызвали скандал и возмущение в Константинополе: автора упрекали в неблагодарности «второму отцу», в клевете и в том, что
Константина подбили сочинить стихи против Льва какие-то «завистливые враги» [10, col. 660B], - отсюда следует, что у Философа, видимо, были при жизни какие-то противники и завистники, что, впрочем, не удивительно при его положении и учености, учитывая к тому же его иконоборческое прошлое в качестве архиепископа Фессалоники. В ответ Константин пишет «Апологию» (авторство для нее императора Льва VI в Patrologia Graeca указано ошибочно), где объявляет все нападки на себя «вздором» и настаивает, что Лев

«издавна, за злом зло испуская,

Матереубийца, как говорится, род Атридов 9

Бесполезную нашел для жизни притчу, -

Я ж, к благому слову благое прибавляя,

В жизни оставлю благочестивое реченье, Отцеубийца нечестивого учителя, -

И пусть эллины хоть, разорвавшись, лопнут ${ }^{10}$, В речах беснуясь совместно с тельхинами! ${ }^{1{ }^{1}}$, $[10$, col. 661A].

Стоит отметить наименование любителей античной образованности и философии «эллины», - которым Константин равняет их по сути с язычниками. Далее он исповедует Христа Богом и проклинает «почитающих эллинских богов» и не поклоняющихся Троице, призывает Христа истребить ереси и погубить раскольников.

Конфликт Константина и Льва свидетельствует о наличии разных течений среди византийских интеллектуалов IX в. - традиционно православного, олицетворяемого Фотием, и более эллинистического и, так сказать, либерального, которое возглавлял Лев Философ. К сожалению, источники ничего не сообщают об отношениях этих двух ученых. Возможно, Фотий в юности учился у Льва это вписывается в хронологию их жизни [4, c. 265-268], - но это всего лишь гипотеза: Фотий не сообщает о своих учителях ничего определенного. В любом случае к концу 840 -х началу 850-х гг. у Фотия должен был сформироваться свой кружок учеников, о деятельности которого патриарх рассказывает в письме к папе Римскому Николаю. «Когда я был дома, - пишет патриарх, - милое удовольствие услад облекало меня, видевшего труд учащихся, усердие вопрошающих, упражнение собеседников, через которые разум настраивает- 


\section{ВИЗАНТИЙСКОЕ ПРАВОСЛАВИЕ}

ся так, чтобы не слишком легко сбивались с пути те, кто изощряет рассудок изучением математики, исследует истину логическими приемами, а божественными Писаниями направляет ум к благочестию, что и есть плод всех других трудов. Ибо таков был сонм моего дома» [2, с. 104]. Отметим здесь у Фотия заботу о том, чтобы разум учеников не совращался с пути при изучении математики и логики - наук светских, то есть как раз тех, которые преподавал в столичном Университете Лев Философ, - и указание на благочестие как плод всех трудов, в чем главная роль отводится изучению Священного Писания.

Хотя речь тут идет о частном образовательном кружке или домашней школе, на уроках Льва и его коллег система обучения была примерно такой же: лекции, вопросы учеников, ответы учителя, практические упражнения.

Единственное сохранившееся письмо Фотия ко Льву посвящено плеоназму глагола

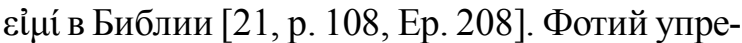
кает Философа за то, что тот критикует за неправильность язык Священного Писания, и призывает отстать от таковой «дерзости» и останавливать ее в других - видимо, прежде всего в учениках. П. Лемерль сомневался, что это письмо направлено именно Льву Философу, а не какому-то другому соименному преподавателю, поскольку тон письма слишком менторский [4, с. 245-246, прим. 72]. Однако время его написания неизвестно, а если письмо относится к 860-м гг., когда Фотий уже был патриархом, такой тон даже по отношению к своему бывшему учителю и к главе столичного Университета в устах главы Церкви не кажется чем-то странным. Впрочем, как мне кажется, Фотий мог писать Льву в таком тоне и в те времена, когда был императорским протоасикритом, занимая высокую должность, обласканный двором, имея свой круг учеников, - тогда как Философ, если он возглавил Университет только после 855 г., а до того занимался частным преподаванием, в какойто степени должен был составлять Фотию конкуренцию. Вероятно, различались и общие направления их «школ», а возможно, и методы преподавания, и материал, на котором упражнялись ученики: Лев был большим любителем античной литературы, не стремился каждый шаг и мысль поверять Писанием и даже не боялся в чем-то его критиковать поведение, пожалуй, не совсем тривиальное для христианина IX в. и преподавателя.

В письме Фотий называет Льва и единодушных ему людей - возможно, членов интеллектуального кружка Философа? - «софистами». С одной стороны, это слово, по античной традиции, могло обозначать просто преподавателя, с другой - в устах благоверного христианина той эпохи оно уже становится скорее ругательным: так, современник Льва диакон Игнатий в Житии св. Никифора, патриарха Константинопольского, говорит, что его герой при составлении речей «удалял приторное и лишнее, и все то, что походило на софистическую бессодержательность и болтовню» [8, с. 12, § 14]; а биограф св. Феодора Студита, как мы уже видели, называет Иоанна Грамматика «превосходным в софизмах», таким образом, «софист» мог обозначать для православных в ту эпоху человека, хорошо образованного светски, но недостаточно благочестивого.

Из письма следует, что Фотий считался признанным специалистом в области филологии, раз Лев решил обсудить с ним вопрос о словоупотреблении, - это согласуется с большим интересом Фотия к лексикологии, очевидном из его сочинений [4, с. 272-278]. П. Магдалино предполагает, что ученые иконоборцы вроде Иоанна Грамматика и эллинисты, подобные Льву Философу, были больше склонны к точным наукам и неоплатонической концепции вселенной, позволяющей рассматривать ее как символическое отражение Бога и благоприятствующей изучению природы - каковое воззрение основывалось не только на платонизме, но и на учении о символической роли всего мироздания у святых Максима Исповедника и Дионисия Ареопагита, а церковные деятели, такие как патриархи Никифор и Фотий или архиепископ Кесарийский Арефа, тяготели к гуманитарным наукам и риторике в соединении со строгим православием; позднее линию Льва продолжил византийский дипломат и ученый Лев Хиросфакт $[19$, p. 66-76]. Такой взгляд содержит упрощение, ведь Лев Философ и Лев Хиросфакт не были профанами в гуманитарных науках и риторике и даже сами занимались поэтическим творчеством. Лев Философ работал как 
филолог, исправляя тексты Платона, которые были в его библиотеке, и является «первым по времени из тех, кто передал нам Платона» [4, с. 247]. Кроме того, Лев и его ученики стояли у истоков сборника эпиграмм, составленного в X в. Константином Кефалой и вошедшего в состав «Палатинской Антологии». В кружке Льва читали и изучали цикл эпиграмм Агафия, у Философа была копия сборника эпиграмм Паллада. Лев прекрасно знал античные эпиграммы; в его кружке были, повидимому, популярны эротические и анакреонтические эпиграммы, поскольку таковые писали ученики Льва Феофан Грамматик и Константин Сицилиец, сочинивший поэму об Эроте - видимо, до своего «обращения» Фотием. Очевидно, что при жизни Льва в Константинополе существовал большой интерес к эллинистической поэзии, Философ и его ученики заново подняли в эпиграммах античные темы [15, p. 100-106, 142].

Однако, если говорить о философских воззрениях обоих Львов, то определенная склонность к христианизированному платонизму в самом деле прослеживается в их сочинениях и деятельности, насколько она нам известна. Говоря об Иоанне Грамматике, родственнике и интеллектуальном предшественнике - а в царствование Феофила, вероятно, и ученом друге - Льва Философа, Магдалино замечает, что его должен был весьма привлекать «тезис, согласно которому астрология, как изучение установленных провидением действий самой прекрасной части божественного творения, равноценна почитанию Господа», и что иконоборцу, который «питал отвращение к изображению воплощенного Бога в виде человека», должна была нравиться идея, что Творец проявляет Свою деятельность не через одни церковные символы, а через всю созданную вселенную; «иначе говоря, правоверие иконоборцев было очень созвучным правоверию астрологов» [19, р. 67]. Связь астрологии с неоплатонизмом существует, но ученый неправ, когда говорит об «отвращении» к иконам как о двигавшем иконоборцами чувством, поскольку ими двигали прежде всего богословско-аскетические соображения: с одной стороны, особое учение об обожении плоти Христа, которое, согласно иконоборцам, происходило не иначе как через посредство души, которую красками изобразить невозможно, что лишает икону причастия божеству и делает «мертвой материей», идолом; с другой - учение о «духовном» поклонении Богу и соединении с ним умственно в молитве, без материального посредства в виде икон, в чем они были близки к платонизму [6, с. 104-110].

Можно ли сказать, что мировоззрение Льва, как утверждает Н. Синиоссоглу, «бросало вызов христианской исключительности» и что Философа вдохновляла «светская версия эллинизма, спрятанная под покрывалом предположительно невинного интереса любителя древностей к оккультному, к предсказаниям и к платонизму»? [24, p. 71] Поэма «Иов, или О беспечалии и терпении» свидетельствует об уважении Льва как к Платону, так и к Аристотелю и другим философам [30, p. 209, стк. $164-165$, и р. 218 , стк. 471], хотя Платона он, очевидно, чтил больше, заботясь о передаче потомкам его сочинений в исправленном и удобочитаемом виде. В то же время Лев и в гомилии на Благовещение Пресвятой Богородицы, которую он произнес в 842 г., будучи архиепископом Фессалоники, и в поэме явно выражает почитание Христа как Бога и Слово и не противоречит каким-либо православным догматам. Вряд ли тут можно говорить о сознательном вызове православию. К тому же следует задаться вопросом: а что такое православие? Если считать его несовместимым с изучением нехристианской литературы, то такого дремучего взгляда никто из образованных византийцев не придерживался. Конечно, православие несовместимо с почитанием языческих богов, но, что бы там ни сочинял Константин Сицилиец, мы не можем приписать Льву Философу веру, которую спустя шесть веков будет исповедовать Георгий Гемист Плифон. Однако увлечение Льва и других византийских гуманистов эллинской философией и толкованием античных текстов и слишком активное использование античных аллюзий и метафор кому-то в самом деле могло показаться признаком отступничества.

Здесь стоит сказать несколько слов о Льве Хиросфакте, ученике Философа и авторе поэмы «Тысячестишное Богословие» [16], который, подобно своему учителю, был обвинен в эллинстве: Арефа Кесарийский возмущался, что Хиросфакт, будучи на самом деле 


\section{ВИЗАНТИЙСКОЕ ПРАВОСЛАВИЕ}

язычником, притворяется христианином и даже дерзает богословствовать [1]. Но имеют ли эти обвинения больше оснований, чем инвективы Константина Сицилийца против Льва Математика? П. Магдалино так характеризует поэму Льва Хиросфакта: «Вместо богословия Воплощения и спасения Хиросфакт представляет провиденциальное действие некоей системы, одновременно обезличенной и одухотворенной, в терминах, явно заимствованных у Григория Назианзина и Псевдо-Дионисия. В согласии с Дионисиевым апофатическим богословием - но также, заметим, и с оригенистской и, следовательно, слегка подозрительной духовностью Евагрия Понтийского, - автор в пространных рассуждениях настойчиво утверждает непознаваемость Бога и невозможность представить Его в конкретных образах. Впрочем, он очень часто использует метафору света для представления Бога и божественной эманации» [19, р. 73]. Исследователь отмечает, что сами по себе формулировки Хиросфакта не имеют ничего неправославного и встречаются у более ранних христианских писателей, «однако то, что не удивило бы у автора VII века, выглядит неожиданно сразу после Торжества православия, которое было торжеством священного изображения», - и предполагает, что Хиросфакт почерпнул основания для такого богословия у своих предшественников, философов эпохи второго иконоборчества $[19$, р. 76]. В попытках вычислить взгляды Льва Философа, исследуя сочинения его ученика, мы вступили бы на довольно зыбкую почву. Но исходя из того что нам известно и учитывая специфику постиконоборческой эпохи и весьма сходные нападки на обоих Львов за их эллинизм и предполагаемое «отступничество» от Христа, мы можем предположить, что использованные ими формулировки, сами по себе не противоречащие православному богословию, в сочетании с ярко выраженной любовью к античной культуре в самом деле возмущали и соблазняли благочестивых христиан эпохи триумфа иконопочитания.

Насколько сознательно использовали оба Льва такие формулировки? Хотели ли они эпатировать православных фундаменталистов своего времени? Был ли это завуалированный протест против строго православных церков- ных рамок, в которые старались загнать верующих после торжества иконопочитания? Являлось ли это сознательным или полусознательным «экспериментированием» с языческой философией? Или это было просто свободное, без задних мыслей, выражение приверженности к красотам античной культуры, выражение традиционно христианского мировоззрения на языке нехристианских авторов, как считает Е. ван Опсталл? [20]

Сейчас нам трудно до конца понять умонастроение византийцев IX в. и, так сказать, заглянуть к ним в душу. Однако можно, повидимому, согласиться с Н. Синиоссоглу, что обвинения в эллинстве были «защитой против появления гуманистического духа» и что византийские гуманисты «оказывались “эллинами" не потому, что они возрождали религию древних, но потому, что отклонялись от православия через экспериментирование в той или иной степени с “языческой” философией и особенно с платонизмом» [24, p. 26 и 66]: противники не могли простить им столь живого интереса к «человеческой мудрости», считая, что этим наносится ущерб мудрости «богооткровенной».

B IX в. византийский гуманизм еще только пробовал почву, и Лев Философ при жизни не только не был осужден за свой эллинизм, но даже попал во святые: согласно Константинопольскому Синаксарю, его память совершается 30 октября ст. ст. [26, col. 178.35-36]. Анафемы против тех, кто посвящает себя эллинским наукам «не только ради образования», но и с целью усвоениях языческих учений, вводят в церковь учения эллинов о человеческой душе и других предметах, превозносят языческих философов и христианских ересиархов выше «благочестивых христиан, по неведению и человеческой слабости как-то погрешивших», грянули позже-в 1076 г., во время процесса против Иоанна Итала [13, р. 5761]. Впрочем, это не угасило в Византии интереса к эллинской культуре и философии, которую к тому же продолжали изучать в школе, как и прежде. Впереди была новая волна византийского гуманизма, олицетворенная в XIV в. великой фигурой Феодора Метохита. Но, к сожалению, правоверные христиане не смогли создать приемлемого синтеза между научным созерцанием ( $\theta \varepsilon \omega \rho i ́ \alpha)$ Метохита и 
молитвенным созерцанием, которое защищал св. Григорий Палама: различие этих двух «созерцаний» окончательно оформилось в поздневизантийскую эпоху [5, с. 110-123], и победа паламизма с его нападками на светские науки и философию привела к усилению в Византии религиозного обскурантизма, - что, в свою очередь, вызвало ответный удар со стороны последнего философа Империи - Плифона, предлагавшего заменить христианство «вечной религией» платонического толка. К сожалению, падение Византии лишило нас возможности увидеть, как сложилась бы там в дальнейшем судьба мирской учености, платонизма и секулярной философии. Однако такие интеллектуалы, как Иоанн Грамматик и Лев Философ, несомненно, являются звеньями той «золотой цепи» передачи античного наследия, которая протянулась к нам сквозь века, несмотря на противодействие христианских фундаменталистов.

\section{ПРИМЕЧАНИЯ}

1 Статья подготовлена при финансовой поддержке РГНФ, грант № 15-03-00093.

${ }^{2}$ Имеется в виду император Лев V.

${ }^{3}$ Имеется в виду иконоборческая ересь.

${ }^{4}$ Под Ассирией в те времена византийцы подразумевали Армению, и Иоанн действительно имел армянское происхождение; см.: [4, с. 197-199; 6, с. 30-31, примеч. 87].

5 Пирифлегетон, или Огнедышащая - в греческой мифологии огненная река в Аиде, впадающая в Ахеронт. Тартар - бездна, находящаяся под царством Аида; здесь служит символом ада.

${ }^{6}$ Хрисипп (281/278-208/205 гг. до н. э.) - древнегреческий философ-стоик, преподавал в Афинах.

7 Говоря так о Гомере, Константин, возможно, не столько выражает не собственную оценку, сколько иронизирует над отношением Льва к поэту.

${ }^{8}$ Арат (315-240 гг. до н. э.) - греческий дидактический поэт, написавший астрономическую поэму «Явления» и поэму «Признаки погоды».

9 Намек на Ореста, сына Агамемнона и Клитемнестры, внука Атрея (чьи сыновья назывались Атридами), убившего свою мать и ее любовника в отместку за убитого ими отца. Здесь эпитет «матереубийца» означает, вероятно, что Лев, по мысли Константина, пошел против «матери-Церкви», отрекшись от православной веры.

${ }_{10}$ Возможно, намек на судьбу Иуды (ср. Деян. 1:18).
11 Тельхины - первые жители острова Родос, слывшие изобретателями литейного и кузнечного дела, кудесниками и оборотнями.

\section{СПИСОК ЛИТЕРАТУРЫ}

1. Арефа Кесарийский. Хиросфакт, или Ненавистник чародейства / пер. М. А. Шангина // Памятники византийской литературы IX-XIV вв. / отв. ред. Л. А. Фрейберг. - М. : Наука, 1969. - С. 49-52.

2. Второе послание патриарха Фотия папе Николаю I (Epistula 290) // Святитель Фотий, патриapx Константинопольский. Антилатинские сочинения / пер. с древнегр. Д. Е. Афиногенова и П. В. Кузенкова. - М. : Общецерковная аспирантура и докторантура им. свв. Кирилла и Мефодия, 2015. C. $102-117$.

3. Кущ, Т. В. На закате империи: интеллектуальная среда поздней Византии / Т. В. Кущ. - Екатеринбург : Изд-во Урал. ун-та, 2013. - 456 с.

4. Лемерль, П. Первый византийский гуманизм. Замечания и заметки об образовании и культуре в Византии от начала до Х в. / П. Лемерль. СПб. : Свое издательство, 2012. - xiv+490 c.

5. Медведев, И. П. Византийскийгуманизм XIVXV вв. / И. П. Медведев. - СПб. : Алетейя, 1997. - 342 с.

6. Сенина, Т. А. (монахиня Кассия). Иконопочитатели и иконоборцы IX столетия / Т. А. Сенина (монахиня Кассия) // Жития византийских святых эпохи иконоборчества / общ. ред. Т. А. Сениной (монахини Кассии). - Т. І. - СПб. : Квадривиум, 2015. - C. 3-130.

7. Сенина, Т. А. (монахиня Кассия). Исторический и культурный контекст творчества Льва Математика и Философа / Т. А. Сенина (монахиня Кассия) // Лев Математик и Философ, Константинопольский. Сочинения / изд. подг. Т. А. Сенина (монахиня Кассия). -СПб. : Алетейя, 2016. - С. 5-51.

8. Творения святого отца нашего Никифора, архиепископа Константинопольского. - Минск, 2001. $-560 \mathrm{c}$.

9. Anthologia Graeca / ed. H. Beckby. - Bd. IIV.-München : E. H. Verlag, 1957-1958.

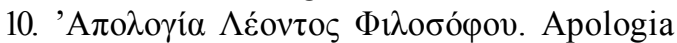
Leontos Philosofou // Patrologia Graeca/ ed. J.-P. Migne. Vol. 107.-Paris : J.-P. Migne, 1863. - Col. 660-661.

11. Evdokimova, A. An Anonymous Treatise against the Iconoclastic Patriarch John the Grammarian. 1. The First Antirrhetic. The First Edition of the Manuscript Escorial Y-II-7, F. 200-205 / A. Evdokimova // Scrinium. Journal of Patrology, Critical Hagiography, and Ecclesiastical History. 2011-2012. - Vol. 7, pt. 1. - P. 144-168.

12. Gouillard, J. Fragments inédits d'un antirrétique de Jean le Grammarien / J. Gouillard 
// Revue des études byzantines. - 1966. - Vol. 24. P. 171-181.

13. Gouillard, J. Le Synodikon de l'Orthodoxie. Édition et commentaire / J. Gouillard // Travaux et mémoires. - 1967. - Vol. 2. - P. 1-316.

14. Katsaros, V. Leo the Mathematician: his literary presence in Byzantium during the 9th century / V. Katsaros // Science in Western and Eastern civilization in Carolingian times / eds. P. L. Butzer and D. Lohrmann. - Basel : Birkhäuser, 1993. - P. 383-398.

15. Lauxtermann, M. D. Byzantine poetry from Pisides to Geometres. Texts and contexts / M. D. Lauxtermann. - Vol. I. - Wien : Verlag, 2003.$390 \mathrm{p}$.

16. Leon Magistros Choirosphaktes. Chiliostichos Theologia / ed. I. Vassis. - Berlin ; N. Y. : W. de Gruyter, 2002. - 240 p.

17. Lilie, R.-J. Ioannes VII. (837-843)/ R.-J. Lilie // Die Patriarchen der ikonoklastischen Zeit. Germanos I. - Methodios I. (715-847) / R.-J. Lilie (Hrsg.). - Frankfurt am Main ; Berlin ; Bern ; N. Y. ; Paris; Wien : P. Lang, 1999. - S. 169-182.

18. Magdalino, P. Occult Science and Imperial Power in Byzantine History and Historiography (9th12th Centuries) / P. Magdalino // The Occult Sciences in Byzantium / eds. P. Magdalino and M. Mavroudi. Geneva : La Pomme d'or, 2006. - P. 119-162.

19. Magdalino, P. L'Orthodoxie des astrologues. La science entre le dogme et la divination à Byzance (VIIe-XIIe siècle) / P. Magdalino. - Paris : Lethielleux, 2006. - $196 \mathrm{p}$.

20. Opstall, E. M. van. Balancing on the Tightrope of Paganism: Leo the Philosopher / E. M. van Opstall // Traditions épiques et poésie épigrammatique. Présence des épopées archaïques dans les épigrammes grecques et latines / éd. Y. Durbec, D. Pralon et F. Trajber. - Leuven : Peeters, 2016. - P. 261-281.

21. Photii patriarchae Constantinopolitani Epistulae et Amphilochia / rec. B. Laourdas et L. G. Westerink. - Leipzig : BSB B. G. Teubner, 1984. Vol. II. -254 p.

22. Pingree, D. Leo the Mathematician / D. Pingree // Complete Dictionary of Scientific Biography. 2008. - Electronic text data. - Mode of access: http:// www.encyclopedia.com/doc/1G2-2830902557.html (date of access: 12.09.2016). - Title from screen.

23. Prosopographie der mittelbyzantinischen Zeit / R.-J. Lilie, C. Ludwig, Th. Pratsch, I. Rochow (Hrsg.). Erste Abt.: 641-867. - Bd. 1-6. - Berlin ; N. Y. : W. de Grunter, 1998-2002.

24. Siniossoglou, N. Radical Platonism in Byzantium: Illumination and Utopia in Gemistos Plethon / N. Siniossoglou. - Cambridge : Cambridge University Press, 2011. -454 p.

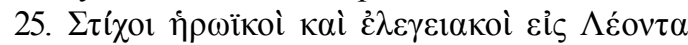

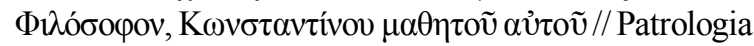

Graeca / ed. J.-P. Migne. - Vol. 107. - Paris : J.-P. Migne, 1863. - Col. LXI, LXIV.

26. Synaxarium Ecclesiae Constantinopolitanae e codice Sirmondiano nunc Berolinensi adiectis Synaxariis selectis / ed. H. Delehaye. - Bruxellis : Apud Socios Bollandianos, 1902. - $1180 \mathrm{col}$.

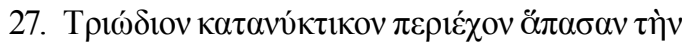

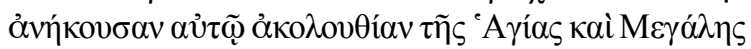

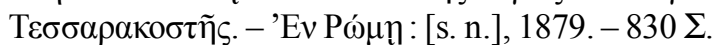

28. Vita et conversatio sancti patris nostri et confessoris Theodori praepositi Studitarum, conscripta a Michaele monacho // Patrologia Graeca / ed. J.-P. Migne. - Vol. 99. - Paris : J.-P. Migne, 1860. Col. 113-232.

29. Vita et conversatio sancti patris nostri et confessoris Theodori abbatus monasterii Studii, a Michaele monacho conscripta // Patrologia Graeca / ed. J.-P. Migne. - Vol. 99. - Paris : J.-P. Migne, 1860. - Col. 233-328.

30. Westerink, L. G. Leo the Philosopher: Job and Other Poems / L. G. Westerink // Illinois Classical Studies. - 1986. - Vol. 11.1/2. - P. 193-222.

31. Wilson, N. G. Scholars of Byzantium / N. G. Wilson. - L. ; Cambridge, Mass. : The Medieval Academy of America, 1996. - 286 p.

\section{REFERENCES}

1. Arefa Kesariiskii. Khirosfakt, ili Nenavistnik charodeistva [Arethas of Caesarea. Choerosphactes, or Wizard-hater]. Transl. by M.A. Shangin. Freiberg L.A., ed. Pamyatniki vizantiyskoy literatury $I X-X I V$ vekov [Monuments of Byzantine Literature of the 9th-14th Centuries]. Moscow, Nauka Publ., 1969, pp. 49-52.

2. Vtoroe poslanie patriarkha Fotiya pape Nikolayu I (Epistula 290) [Second Epistle of Patriarch Photius to Pope Nicholas (Epistle 290)]. Transl. by D.E. Afinogenov, P.V. Kuzenkov. Sviatitel Fotiy, patriarkh Konstantinopolskiy. Antilatinskie sochineniya [St. Photius, Patriarch of Constantinople. Anti-Latin Writings]. Moscow, Obshchetserkovnaya aspirantura i doktorantura im. sv. Kirilla i Mefodiya, 2015, pp. 102-117.

3. Kushch T.V. Na zakate imperii: intellektualnaya sreda pozdney Vizantii [On the Decline of the Empire: the Intellectual Environment of Late Byzantium]. Ekaterinburg, Izd-vo Ural. un-ta, 2013. 456 p. 4. Lemerl P. Pervyy vizantiiskiy gumanizm. Zamechaniya $i$ zametki ob obrazovanii $i$ kulture $v$ Vizantii ot nachala do Xv. [First Byzantine Humanism. Notes and Remarks on Education and Culture in Byzantium From Its Origins to the 10th Century]. Saint Petersburg, Svoe izd-vo, 2012. xiv+490 p.

5. Medvedev I.P. Vizantiyskiy gumanizm XIV$X V v v$. [Byzantine Humanism of the 14th-15th Centuries]. Saint Petersburg, Aleteya Publ., 1997.342 p. 
6. Senina T.A. (nun Kassia). Ikonopochitateli i ikonobortsy IX stoletiya [The Iconophiles and the Iconoclasts of the Ninth Century]. Senina T.A. (nun Kassia), ed. Zhitiya vizantiyskikh sviatykh epokhi ikonoborchestva. T. 1 [The Lives of Byzantine Saints of the Iconoclastic Epoch. Vol. I]. Saint Petersburg, Kvadrivium Publ., 2015, pp. 3-130.

7. Senina T.A. (nun Kassia). Istoricheskiy i kulturnyy kontekst tvorchestva Lva Matematika i Filosofa [The Historical and Cultural Context of the Work of Leo the Mathematician and Philosopher]. Senina T.A. (nun Kassia), ed. Lev Matematik i Filosof, Konstantinopolskiy. Sochineniya [Leo the Mathematician and Philosopher. Works]. Saint Petersburg, Aleteya Publ., 2016, pp. 5-51.

8. Tvoreniya svyatogo ottsa nashego Nikifora, arkhiepiskopa Konstantinopolskogo [Works of our Holy Father Nicephorus, Archbishop of Constantinople]. Minsk, 2001. 560 p.

9. Beckby H., ed. Anthologia Graeca. Vols. I$I V$. München, E. H. Verlag, 1957-1958.

10. 'A ed. Patrologia Graeca, 1863, vol. 107, pp. 660-661.

11. Evdokimova A. An Anonymous Treatise against the Iconoclastic Patriarch John the Grammarian. 1. The First Antirrhetic. The First Edition of the Manuscript Escorial Y-II-7, F. 200-205. Scrinium. Journal of Patrology, Critical Hagiography, and Ecclesiastical History, 2011-2012, vol. 7, no. 1, pp. 144-168.

12. Gouillard J. Fragments inédits d'un antirrétique de Jean le Grammarien. Revue des études byzantines, 1966, vol. 24, pp. 171-181.

13. Gouillard J. Le Synodikon de l'Orthodoxie. Édition et commentaire. Travaux et mémoires, 1967, vol. 2, pp. 1-316.

14. Katsaros V. Leo the Mathematician: his literary presence in Byzantium during the 9th century. Butzer P.L., Lohrmann D., eds. Science in Western and Eastern civilization in Carolingian times. Basel, Birkhäuser, 1993, pp. 383-398.

15. Lauxtermann M.D. Byzantine poetry from Pisides to Geometres. Texts and contexts. Vol. I. Wien, Verlag, 2003.390 p.

16. Leon Magistros Choirosphaktes. Chiliostichos Theologia, ed. I. Vassis. Berlin; New York, W. de Gruyter, 2002. 240 p.

17. Lilie R.-J. Ioannes VII. (837-843). Lilie R.-J., ed. Die Patriarchen der ikonoklastischen Zeit. Germanos I. - Methodios I. (715-847). Frankfurt am Main; Berlin; Bern; New York; Paris; Wien, P. Lang, 1999, pp. 169-182.

18. Magdalino P. Occult Science and Imperial Power in Byzantine History and Historiography (9th12th Centuries). Magdalino P. and Mavroudi M., eds.
The Occult Sciences in Byzantium. Geneva, La Pomme d'or, 2006, pp. 119-162.

19. Magdalino P. L'Orthodoxie des astrologues. La science entre le dogme et la divination à Byzance (VIIe-XIIe siècle). Paris, Lethielleux, 2006. 196 p.

20. Opstall E.M. van. Balancing on the Tightrope of Paganism: Leo the Philosopher. Durbec Y., Pralon D., Trajber F., eds. Traditions épiques et poésie épigrammatique. Présence des épopées archaïques dans les épigrammes grecques et latines. Leuven, Peeters, 2016, pp. 261-281.

21. Laourdas B., Westerink L.G. Photii patriarchae Constantinopolitani Epistulae et Amphilochia. Leipzig, BSB B.G. Teubner, 1984, vol. II. $254 \mathrm{p}$.

22. Pingree D. Leo the Mathematician. Complete Dictionary of Scientific Biography, 2008. Available at: http://www.encyclopedia.com/doc/1G2-283090255 7.html. (accessed September 12, 2016).

23. Lilie R.-J., Ludwig C., Pratsch Th., Rochow I., eds. Prosopographie der mittelbyzantinischen Zeit. Erste Abt.: 641-867. Vols. 1-6. Berlin; N. Y., W. de Grunter, 1998-2002.

24. Siniossoglou N. Radical Platonism in Byzantium: Illumination and Utopia in Gemistos Plethon. Cambridge, Cambridge University Press, 2011. $454 \mathrm{p}$.

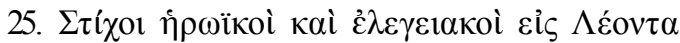

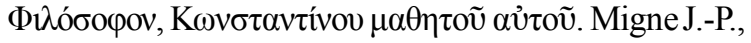
ed. Patrologia Graeca, 1863, vol. 107. Paris, J.-P. Migne, col.LXI, LXIV.

26. Delehaye H., ed. Synaxarium Ecclesiae Constantinopolitanae e codice Sirmondiano nunc Berolinensi adiectis Synaxariis selectis. Bruxellis, Apud Socios Bollandianos, 1902. 1180 p.

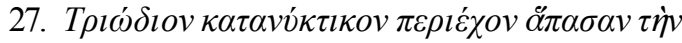

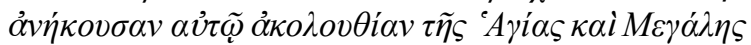

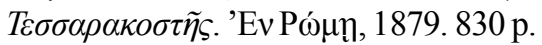

28. Vita et conversatio sancti patris nostri et confessoris Theodori praepositi Studitarum, conscripta a Michaele monacho. Migne J.-P., ed. Patrologia Graeca. Paris, J.-P. Migne, 1860, vol. 99, pp. 113-232.

29. Vita et conversatio sancti patris nostri et confessoris Theodori abbatus monasterii Studii, a Michaele monacho conscripta. Migne J.-P., ed. Patrologia Graeca. Paris, J.-P. Migne, 1860, vol. 99, col. 233-328.

30. Westerink L.G. Leo the Philosopher: Job and Other Poems. Illinois Classical Studies, 1986, vol. 11.1/ 2, pp. 193-222.

31. Wilson N.G. Scholars of Byzantium. London; Cambridge, Mass., The Medieval Academy of America, 1996. 286 p. 


\section{ВИЗАНТИЙСКОЕ ПРАВОСЛАВИЕ}

\section{Information About the Author}

Tatyana A. Senina (nun Kassia), Candidate of Sciences (Philosophy), Saint Petersburg State University of Aerospace Instrumentation, B. Morskaya St., 67, 190000 Saint Petersburg, Russian Federation, mon.kassia@gmail.com.

\section{Информация об авторе}

Татьяна Анатольевна Сенина (монахиня Кассия), кандидат философских наук, СанктПетербургский государственный университет аэрокосмического приборостроения, ул. Б. Морская, 67, 190000 г. Санкт-Петербург, Российская Федерация, mon.kassia@gmail.com. 